\title{
Failure to Infuse
}

National Cancer Institute

\section{Source}

National Cancer Institute. Failure to Infuse. NCI Thesaurus. Code C63174.

Failure (=complete nonperformance) with regard to the intended function of infusion. 